\title{
HEMOLYTIC ANTIBODIES FOR SHEEP AND OX ERYTHROCYTES IN INFECTIOUS MONONUCLEOSIS ${ }^{1}$
}

\author{
By G. HOWARD BAILEY AND SIDNEY RAFFEL \\ (From the Department of Immunology, School of Hygiene and Public Health, \\ The Johns Hopkins University, Baltimore)
}

(Received for publication October 22, 1934)

Paul and Bunnell (1932) observed very high concentrations of agglutinins and hemolysins for sheep cells in the sera of patients during the acute stages of infectious mononucleosis, and this observation was found by these investigators to be of much value in the diagnosis of the disease. This finding has been confirmed and extended by Rosenthal and Wenkebach (1933), Boveri (1933), Bunnell (1933) and Bernstein (1934). In addition to the practical application in diagnosis, theoretical interest centers about the fact that antibodies for sheep cells are produced or enhanced in a disease of unknown etiology. Paul and Bunnell offered two explanations for their findings: (1) that the unknown agent responsible for infectious mononucleosis contains the heterophile or Forssman antigen; (2) that they were dealing with an example of isoagglutinin production elicited by abnormal cells, which are present either in the blood, or elsewhere, during active stages of the disease.

In studies of infectious mononucleosis by different investigators, a probable bacterial origin has often been suggested, with special mention of the streptococcus group, diphtheroid bacilli, and Vincent's organisms, all of which have been found in nose, mouth or throat lesions during the disease. Nyfeldt (1929) has reported the isolation of a small V-shaped or curved gram positive organism from the blood, which he called Bacterium monocytogenes hominis, and with which he produced the cellular blood picture of infectious mononucleosis in rabbits. Agglutination of this organism in 1 to 250 dilution by the serum of the patient was observed, but only five days after the temperature had become normal. Gorham, Smith and Hunt (1929) claimed to have produced the typical blood picture of the disease in guinea pigs by inoculation of membrane from the pharynx of

\footnotetext{
1 Supported in part by a grant-in-aid from the $\mathrm{Na}$ tional Research Council.
}

a severe case of Vincent's angina, while persons in contact with the experimental animals developed infectious mononucleosis. According to these investigators, heat-killed Vincent's spirochaetes also produced the blood picture in guinea pigs with subsequent immunity. The results mentioned above as to the etiology of infectious mononucleosis have not been confirmed.

The more recent studies on the antibody response in infectious mononucleosis seemed to us to offer a new angle of approach to the possible determination of the etiological agent and to an analysis of the properties of the blood serum in this disease. All the authors who have reported on the antibody response have used the terms heterophile or Forssman antibody in describing the sheep cells agglutinin and hemolysin in the sera of patients with infectious mononucleosis, on the assumption that the immune bodies are true Forssman antibodies merely because of their action on sheep cells. No results are recorded concerning absorption or other tests with various heterophile and non-heterophile antigens, such as guinea pig tissues and ox red cells respectively. In studies on the immunological properties and relationships of pneumococci and other organisms by Bailey and Shorb (1931, 1933a and b) and by Shorb and Bailey (1934), the observations by these workers and many others on the heterophile and non-heterophile antigens of various animal and bacterial species have been summarized. The results are given below.

Common or similar properties are often found in the normal and immune sera of man and many animal species and in the so-called heterogenetic antigens in certain animals and bacteria. The heterogenetic antigen most extensively studied was first observed by Forssman (1911) who found a substance in emulsions of the tissues of the guinea pig, cat and horse but not in the ox and rat, which stimulated in rabbits an hemolysin for sheep red corpuscles. The terms "heterologous," "heterogenetic," and "Forssman" have often been used in referring to these substances which have an antigenic 
factor in common with sheep red cells. It is known, however, that sheep red cells contain at least two and probably more distinct antigens; one of them in common with ox red cells is thermolabile and gives rise to a species or group specific hemolysin in rabbits, the other resists boiling, and stimulates in rabbits an hemolysin which is not species or group specific. To the former Friedemann (1917) applied the term "isophile" and to the latter the name "heterophile" (i.e., having an affinity for the receptors of other and phylogenetically unrelated species). These terms are better chosen since they can be applied both to the antigen and antibody while the term heterogenetic refers only to the ability of the antigen to engender antibodies for such unrelated species.

A large number of animals and bacteria possess chemical and immunological properties practically indistinguishable from the thermostable substance found in sheep red cells. The animals having heterophile antigen in their tissues or blood are said to belong to the "guinea pig type" and those not having it are classed as the "rabbit type." Alcoholic extracts of heterophile antigens are capable of inhibiting in vitro the action of heterophile hemolysins when mixed with them, of fixing complement in their presence and of precipitating these antibodies; but such extracts act only in this way as "haptens" because they are incapable of stimulating the production of hemolysin in vivo unless combined with a protein or other suitable colloid. Furthermore, heterophile antibodies can be removed from solution by absorption with heterophile antigens; they generally have the property of primary toxicity for the guinea pig; and in many cases they will agglutinate as well as hemolyze sheep red blood cells, although the ratio of hemolysins and agglutinins may vary greatly. Heterophile antibodies can be produced only in animals of the rabbit type, while isophile antibodies can be produced in both the rabbit and guinea pig types.

It is well known that an immune serum from the rabbit, obtained by injecting ox red corpuscles, contains a certain amount of hemolysin for the sheep's red corpuscles as well as for those of the ox; the same is true for both species of cells if sheep red cells are injected instead of ox cells. These hemolysins are engendered by the thermolabile isophile or group antigens of these zoologically related species. It is known too that ox red cells also possess a thermostable substance which has, however, entirely different antigenic properties from the ordinary thermostable Forssman component of sheep red cells. Whether ox cells and sheep cells have identical or similar thermostable factors in common has not been determined. It has been shown by Landsteiner and van der Scheer (1925) by means of the flocculation reaction, that similar substances or common factors exist even in the blood of many distantly related species, which can be extracted from the blood with alcohol. It was further shown that in some instances an immune serum may not be markedly hemolytic for a certain blood and still contain an antibody active upon a fraction thereof, as in the case of the flocculation of anti-horse sera by rat blood extracts. Such reactions are not true heterophile reactions of the Forssman type, but they are heterogenetic in the broadest sense of this term.

The blood of human beings and rabbits normally contains heterophile (Forssman) hemolysin of low titer for the red corpuscles of the sheep, but no isophile hemolysin is found naturally in the serum of either of these species. In human beings with certain clinical conditions antibodies for sheep red cells have been shown to be greatly increased in amounts and to be of definite value in diagnosis. Thus, Davidsohn $(1929,1930)$ has demonstrated a marked rise in the titers of lysins and agglutinins for sheep red cells (and a slight increase for the red cells of the ox, guinea pig and rabbit) in the sera of patients who had been injected with horse serum, and that the average titers for these antibodies were very much higher among those patients who subsequently developed serum sickness than among those who did not develop allergic symptoms. Since horse serum contains some heterophile antigen it was to be expected that the antibodies for sheep cells were mostly of the Forssman type. This was shown to be the case by Ramsdell and Davidsohn (1930) and Davidsohn and Ramsdell $(1929,1930)$ by means of absorption tests with known heterophile antigens, such as guinea pig tissues, and by the increased primary toxicity of the sera for this animal. Similar results were found by Bailey and Shorb (1931) who noted an increase in the hemolytic titers of the sera of patients who were recovering from lobar pneumonia, a disease caused by the pneumococcus, all types of which were shown by them to contain the Forssman antigen.

With these observations in mind we have made the present study with the object of determining more definitely the serological properties and relationships of the hemolytic and agglutinative antibodies in infectious mononucleosis. The results of this study comprise the present report.

\section{METHODS}

Serum titrations. The sera were titrated both for agglutination and hemolysis of the various cells used. In the agglutination tests, $1.0 \mathrm{cc}$. of the various dilutions of inactivated serum plus $0.5 \mathrm{cc}$. of a two per cent suspension of washed erythrocytes were used in each tube. This was incubated in the water bath at $37.5^{\circ} \mathrm{C}$. for one hour, placed in the icebox over night, and then read for macroscopic agglutination. The highest dilutions showing a complete $(4)$ and a definite $(+)$ positive reaction were recorded. Tubes showing \pm agglutination were not regarded as significant.

Hemolytic titrations were carried out in two ways. In the absorption method, the same sets which had been read for agglutinins were used. After recording these values, the supernatant sera were drawn off the cells and $1.0 \mathrm{cc}$. of isotonic saline was added to each tube, followed by 0.2 cc. of pooled fresh guinea pig serum diluted 1 to 10 . 
The racks were well shaken, incubated for one hour at $37.5^{\circ} \mathrm{C}$. in the water bath, and read for hemolysis. The second method was the direct titration of the serum. To the dilutions of serum in $1.0 \mathrm{cc}$. volumes was added 0.5 cc. of two per cent red cell suspension, followed by the same guinea pig complement. The tubes were shaken and incubated at $37.5^{\circ} \mathrm{C}$. in the water bath for one hour. The absorption method was favored because it eliminated the possibility of anticomplementary action of the serum. Both methods were used as checks on each sample of serum. The titer of hemolysins was determined from the highest dilution of serum showing complete hemolysis. The last tube showing definite $(+)$ lysis was also recorded.

It is to be noted that in these tests $1.0 \mathrm{cc}$. of serum dilution was used in each tube, so that the titers recorded indicate the number of units of agglutinin or hemolysin per cubic centimeter of the original undiluted serum. Attention is brought to this because previous authors (Paul and Bunnell (1932), Bunnell (1933), Boveri (1933), Bernstein (1934)) who have reported on infectious mononucleosis have followed the technic of Davidsohn (1929), in which $0.5 \mathrm{cc}$. of each serum dilution was used. For purposes of comparison the titers indicated in this paper are therefore actually double those which would be recorded by Davidsohn's method.

Absorption tests. These tests were carried out with a variety of heterophile and other antigens. The method used was essentially that employed by Bailey and Shorb (1931, 1933b), and is briefly as follows :

The serum to be absorbed was diluted so that $1.0 \mathrm{cc}$. contained a convenient number of units of antibody, usually forty or eighty. About 0.2 to $0.4 \mathrm{cc}$. of the finely divided absorbing antigen was packed by rapid centrifugalization and the supernatant saline was carefully drawn off completely. To the wet absorbing antigen in the centrifuge tube, $1.0 \mathrm{cc}$. of the diluted serum was added, the two thoroughly mixed, and incubated in the water bath at $37.5^{\circ} \mathrm{C}$. for two hours. The mixture was then centrifuged at high speed for a few minutes and $0.5 \mathrm{cc}$. of the supernatant fluid was drawn off and diluted in a series of serological tubes. One unit of the red cells against which the serum was to be titrated was added to each tube and the incubation again carried out at $37.5^{\circ} \mathrm{C}$. for one hour. The set was then placed in the icebox over night, and the next morning was read for agglutinins. The supernatant fluids were now pipetted off and $1.0 \mathrm{cc}$. of salt solution was added to each tube for resuspension of the cells. Complement was added and the tubes were again incubated at $37.5^{\circ} \mathrm{C}$. for one hour and then read for hemolysis. Control series in which the sera were not absorbed, but were otherwise treated similarly to the absorbed samples, were always run for comparison. In determining the extent of absorption of agglutinins or hemolysins, the test sets were compared with the controls.

The number of units of antibody used in each test varied between 40 and 160 , though 40 or 80 units were used in most instances. Because of this variation, however, absorption values in the tables are given in terms of per cent of total antibodies absorbed, rather than as absolute figures.

The absorbing antigens used were either tissues, bacteria or erythrocytes. The tissues were finely ground, and 0.2 to $0.4 \mathrm{cc}$. of the packed material was used for each test, depending on the number of units of antibody to be absorbed. The bacteria were grown in 0.5 per cent glucose beef infusion broth (with vaseline seals for the anaerobes) for as long a period as necessary to obtain a heavy growth, usually 24 hours. The packed bacteria of 50 or $100 \mathrm{cc}$. of broth culture were used in each test, depending on the units of antibody to be absorbed. The erythrocytes were used in the ratio of 10 units of packed cells for each 40 units of antibody to be absorbed. Bailey and Shorb (1933b) have shown that 10 units of boiled sheep red cells may remove from 760 to 930 units of hemolysin from heterophile rabbit sera. The details of treatment of the antigens (heating, etc.) are indicated in the absorption tables.

Neutralization tests. Tests were carried out with salt solution emulsions of alcoholic extracts of various tissues and bacterial and blood cells. It is well known that such emulsions of the lipoids of heterophile antigens combine with the corresponding antibody. The extracts were employed in order to determine the possibility of their interference with the sensitization of the red cells by the infectious mononucleosis antibodies. The preparation of the extracts is described by Bailey and Shorb (1933a and b). The alcoholic emulsions were made by the slow addition, with shaking, of $4.5 \mathrm{cc}$. of saline to $0.5 \mathrm{cc}$. of extract. Fairly opalescent emulsions were obtained in this manner. All the extracts of Forssman antigens used here have been repeatedly tested for their ability to neutralize heterophile hemolysins and found effective. These tests were carried out in essentially the same manner as the absorption tests. Serial dilutions of the serum were put in serological tubes, $0.5 \mathrm{cc}$. of lipoid emulsion was added to each tube, and the mixtures were incubated for two hours in the water bath at $37.5^{\circ} \mathrm{C}$. One unit of red cells was then added to each tube. From this point onward the technic was the same as that used in the absorption tests.

\section{CLINICAL ASPECTS OF CASES REPORTED}

This report deals primarily with the immunological findings in three clinically and serologically definite cases of infectious mononucleosis. Evidence is offered which supports the conclusion that the antibodies in this disease are not heterophile or Forssman immune bodies, a fact which may be of value in the diagnosis of this condition as well as in the explanation of certain phenomena which occur in the disease. The clinical data in these cases are given below and the temperature curves and blood pictures are illustrated in Figures 1,2 and 3 . 
Case $1 .^{2}$ F. C., a white, male, medical student, aged 22 years, was admitted to The Johns Hopkins Hospital on November 28, 1933, complaining of malaise and severe headache of three days duration. The temperature on admission was $101.5^{\circ} \mathrm{F}$.

Examination at the time of admission showed nothing striking. There was no gingivitis. A vestigial remnant of tonsil on the right side was moderately hyperemic, as was the pharynx. There was a leukopenia at this time, the white cell count being 3,250. The differential count was normal, however, nor were any cellular abnormalities noted. Within the next week, changes occurred which pointed to the correct diagnosis. There was occa- completely recovered and was discharged from the hospital.

Blood culture was negative on the third day of hospitalization. On the fifth day a culture of the throat revealed Staph. aureus and albus, and an alpha hemolytic streptococcus.

The blood serum on the fifth day agglutinated $B$. $t y$ phosus, $B$. paratyphosus $B$ and $B$. suipestifer $I$ all in dilutions of 1 to 160 . It should be noted that the patient had received typhoid vaccine in 1927 . Three days later the bacterial agglutinations were: $B$. typhosus, 1 to 80 ; $B$. paratyphosus $A, 1$ to 20 ; and $B$. paratyphosus $B, 1$ to 320.

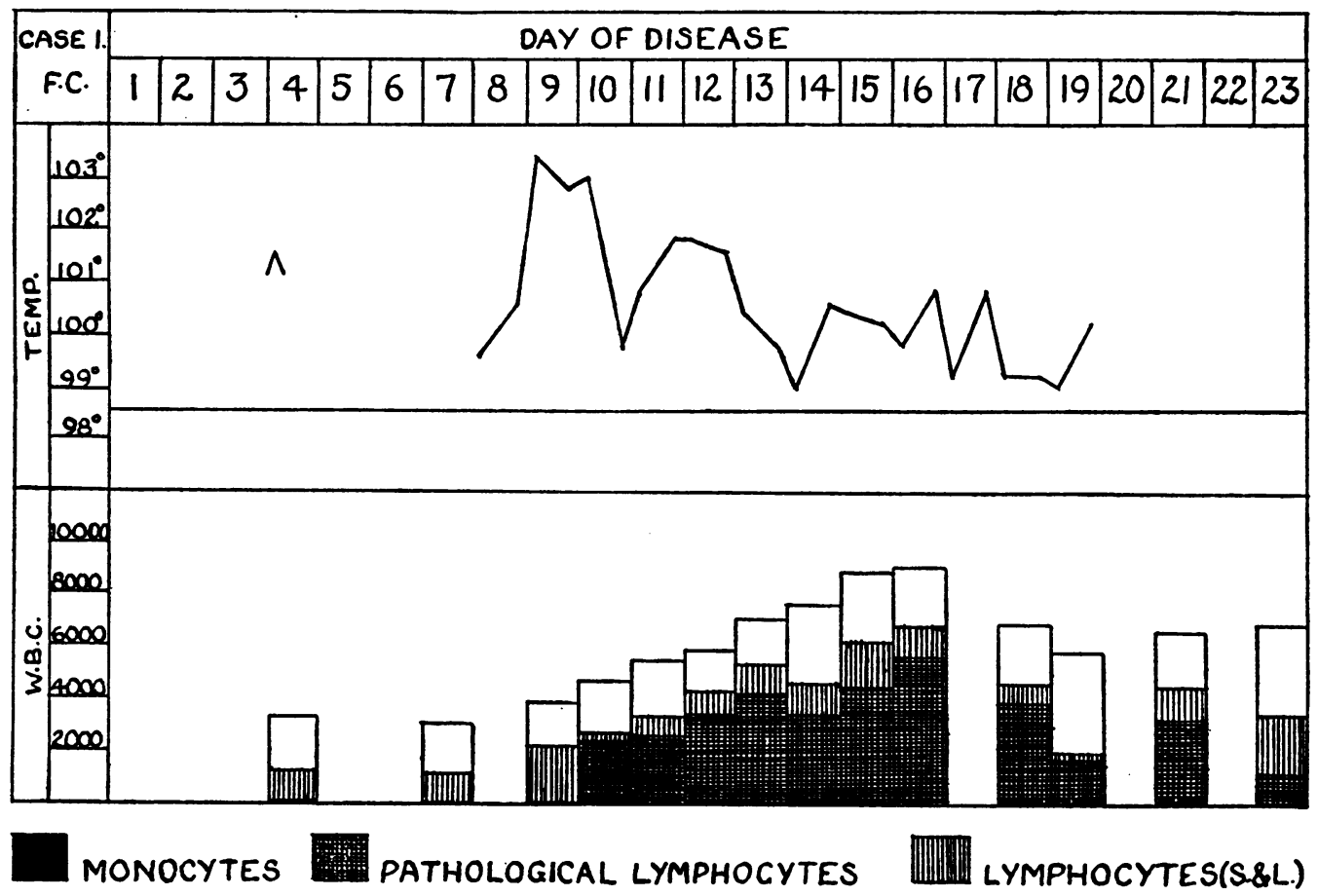

Fig. 1. Case 1. Infectious Mononucleosis.

sional nausea, and on one occasion, spontaneous epistaxis. The throat was injected but only slightly sore. The cervical glands and the spleen became definitely palpable. At this time the abnormal lymphocytes characteristic of infectious mononucleosis first appeared, and the serum on December 4 agglutinated sheep erythrocytes in 1 to 64 dilution. Symptoms continued for 10 days longer. The temperature course and blood findings are shown in Figure 1. On the twenty-second day the patient had

2 The authors are indebted to Dr. Alan Bernstein of The Johns Hopkins Hospital for clinical data and blood samples from this patient. The case was reported as Case 14 in the series presented by Dr. Bernstein in his paper, "Antibody Responses in Infectious Mononucleosis," J. Clin. Invest., 1934, 13, 419-435.
Agglutination of sheep erythrocytes occurred in 1 to 64 dilution when first tested for on the sixth day after admission, the same day on which the characteristic symptoms and pathological blood cells of the disease were first noted. Two days later the agglutinins had risen to 1 to 256 , and six days after this they reacted in a dilution of 1 to 4,096 .

For experimental purposes, aseptically collected blood and nose and throat swabs were obtained on December 13, fifteen days after admission, at a time when the patient had a rather severe sore throat.

The serum was separated from the clot, the latter was macerated in a sterile mortar, broth was 
added as a diluent, and it was inoculated into agar and rabbit blood broth tubes, as well as into a rabbit, a guinea pig, a rat, and a mouse. The tubes remained sterile, nor did any of the animals show any indication of an infectious process.

Culture of the nose and throat swabs revealed Staph. albus, and alpha and gamma hemolytic streptococci. Part of the nose and throat swab broth washings were injected intraperitoneally into a rabbit, guinea pig, rat and mouse. No visible reactions occurred in the first three animals, but the mouse died within 96 hours. Gram positive diplococci and short chains were found in pure form in smears from the heart blood and peritoneal and thoracic cavities. These were iso-
Case 2. N. H., a white, male, graduate student, aged 22 years, was seen on July 11, 1934, at which time the complaint included a severe soreness of the throat and gums and general adenopathy. During the preceding two weeks the patient had noted a fatigued feeling and frequent headaches on arising in the morning, which gradually subsided during the course of the day. Five days before, the soreness of the throat and gums had set in, and at this time enlargement of the cervical glands in the anterior triangle on the right side was first noticed by the patient. These symptoms had become progressively more severe to the time of examination.

At the time the patient was first seen, the temperature was $100^{\circ} \mathrm{F}$. The right anterior cervical and right inguinal glands were enlarged and tender, and the axillary nodes also were slightly palpable. The spleen and liver could not be felt. The soft palate was congested and bore an area of ulceration about one centimeter in diame-

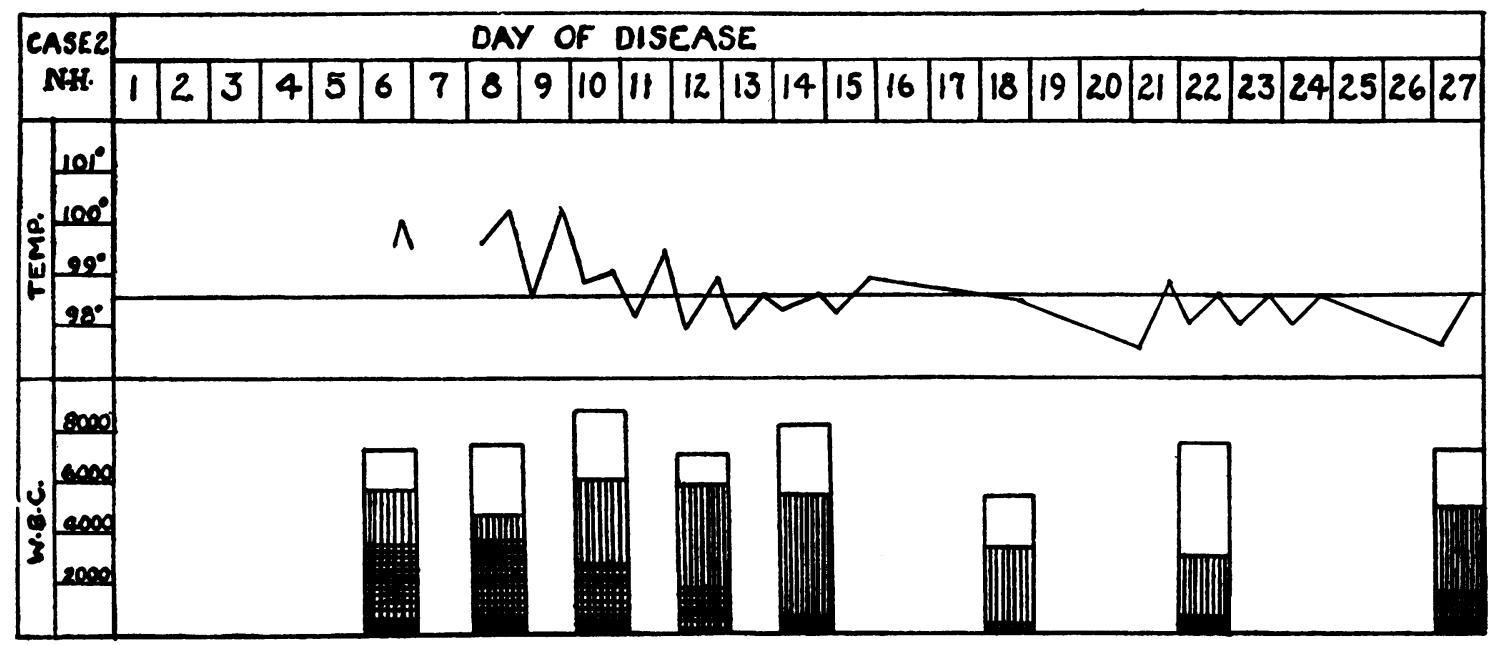

Fig. 2. CASE 2. Infectious Mononucleosis.

Legends as in Figure 1.

lated on rabbit blood agar and proved to be gamma streptococci.

Nose and throat cultures were again made on the day of discharge from the hospital, when the patient had completely recovered from symptoms. At this time only a hemolytic staphylococcus (albus) was recovered.

All the organisms thus isolated were used for attempted absorption of antibodies from the patient's serum, in an effort to establish a possible etiological relationship to the disease. The results of these tests are given in a subsequent section.

The second case showing the clinical and serological features of the disease is reported below. ter which was covered with a white diphtheritic membrane. A culture of this was negative for $B$. diphtheriae. The total leukocyte count at this time was normal and remained within normal limits during the subsequent course of the illness. The differential, however, showed 72 per cent lymphocytes, of which 41 per cent were the pathological forms typical of infectious mononucleosis. The temperature course and additional leukocyte studies are shown in Figure 2. Agglutination of sheep cells in a dilution of 1 to 1,024 with serum obtained on July 13 confirmed the diagnosis.

Subsidence of symptoms and recession of the lymph glands began after six days, though a "weak" feeling of the gums continued. These were not markedly inflamed, but on the right side they showed the beginning of an ulcerative stomatitis which was found to harbor a profusion of spirochaetes and fusiform bacilli. Within a week this had developed into a severe Vincent's angina. This 
yielded to specific treatment, whereupon complete recovery ensued.

Bacterial agglutinations with serum collected on July 18 were negative in dilutions of 1 to 20 with $B$. typhosus, $B$. paratyphosus $A, B$. paratyphosus $B, B$. suipestifer, $B$. abortus, and $B$. proteus $X 19$, but a test with $B$. melitensis was positive in 1 to 80 dilution.

Six days after the patient was first seen, a swab of the soft palate on and around the membrane showed Staph. albus and a gamma streptococcus. These were used for absorption of the serum, as reported further on.

It is of interest that this patient was kept at home during the entire course of his illness, with no precautionary measures as to contact with other members of the family. Several of these were within the age range for infectious mononucleosis (between 18 and 25 years), yet no contagiousness nor infectiousness by ordinary contacts was apparent. Gorham, Smith and Hunt (1929) have reported transmission of the disease between experimental animals and laboratory workers in contact with them, as well as between human beings.

The course of the third case is presented below.

Case 3.3 F. W., a white, female, nurse, aged 36 years, was admitted to the Sinai Hospital on September 18, 1934, complaining of pain in the back on both sides, enlarged glands, sore throat, and very severe headache.

Eight days before admission, the patient suffered severe pains in the right and lower regions of the back. The pain was intermittent and radiated toward the umbilicus, but not to the right shoulder or scapula. At this time, she noticed also that her cervical, axillary and inguinal glands were enlarged and tender. Coincident with this there was a constant dull headache in the frontal and parietal areas. Four days later the pain in the lower back extended to the left side and this continued up to the day before admission. During this period the patient had been nauseated constantly and had noted that her stools were very light in color. She now became aware of the fact that her skin had assumed a light yellow tinge. At the same time she began to feel chilly and feverish. By the day of admission the jaundice had to a great extent subsided.

The morning of the day before admission the patient vomited large white curds after drinking milk, and during the remainder of the day suffered a dull pain in the epigastrium, which was no longer present at the time of examination. On the same day her throat became very sore.

8 The authors wish to express their thanks to Dr. L. F. Krumrein and Dr. L. Katzenstein of the Sinai Hospital, Baltimore, for the clinical data and blood of this patient.
On admission, the temperature was $101^{\circ} \mathrm{F}$. There was an icteric tint to the sclerotics, the pharynx was granular, and the pillars inflamed. The cervical, axillary and inguinal nodes were enlarged. The liver and spleen were not palpable. The icteric index was 50 , and immediate biphasic van den Bergh reactions were obtained. The total leukocyte count at this time was 9,700 , with 80 per cent lymphocytes, most of which were of the characteristically abnormal type. The subsequent temperature course and differential blood pictures are illustrated in Figure 3.

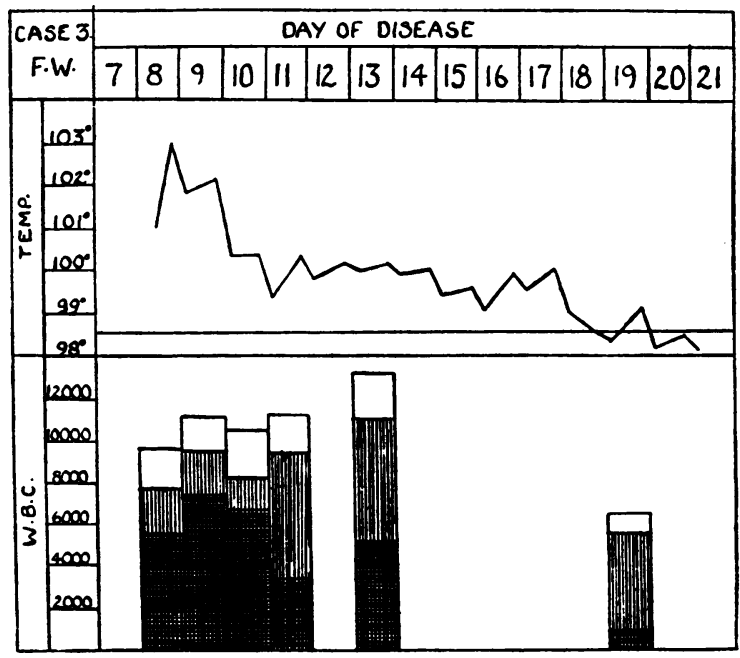

Fig. 3. Case 3. Infectious Mononucleosis. Legends as in Figure 1.

After four days, the symptoms diminished in severity, and the glandular enlargement became less pronounced. The sclerotics were still slightly icteric, but $\mathbf{x}$-ray revealed no gallbladder pathology. On the fourteenth day the patient was discharged from the hospital.

The Wassermann reaction on September 19 was negative. On September 21 the serum agglutinated sheep erythrocytes through a dilution of 1 to 512, which was the lowest concentration of serum tested. The next day definite agglutination of these cells was found in 1 to 4,096 .

Throat culture on admission revealed a hemolytic staphylococcus. A blood culture made the next day was negative.

On September 22, at the time when the acute symptoms had begun to subside, blood was obtained aseptically and defibrinated. Within 30 minutes of collection, the whole blood was transferred to the following media: (1) patient's blood incorporated in beef infusion agar, (2) patient's blood in beef infusion broth, (3) normal human erythrocyte beef infusion agar, (4) normal hu- 
man erythrocytes in small amount of normal plasma, (5) rabbit blood beef infusion agar, (6) rabbit blood beef infusion broth, (7) chocolate rabbit blood beef infusion agar, (8) ox spleen infusion broth, (9) ox lung infusion broth (with and without glucose, both aerobic and anaerobic), (10) ox brain infusion broth (with and without glucose, both aerobic and anaerobic), (11) ox liver infusion broth, and (12) sheep hemoglobin infusion agar.

After prolonged incubation at $37.5^{\circ} \mathrm{C}$, no growth was found in these tubes by staining methods, though certain of them were suggestively turbid. The contents of the turbid tubes, together with a small amount of the patient's defibrinated blood, were injected intravenously into rabbits. These developed hemolysins for sheep cells in titers as high as 1 to 1,660 on the seventh day after the last injection. Further studies on this point are now being carried on, the results of which will be reported in a later paper."

\section{Serology}

Titrations. In Table I are tabulated the titers of sera collected at intervals during the active stages of illness in the three cases described. In Cases 1 and 2, results obtained with serum collected some time after recovery are also shown. Titrations were carried out against sheep and ox red cells.

The parallelism of agglutinin and hemolysin values for sheep erythrocytes in the sera obtained during the illness is striking in all instances except with the first sample in Case 2 where the endpoint of hemolysis was considerably lower than that for agglutination. In Case 3 also the endpoints are considerably separated, though the difference here indicates a variation of only one tube in the series of serum dilutions. The values of complete agglutination and hemolysis in this instance are quite close. Paul and Bunnell have previously discussed the parallelism of the antibodies in this disease.

In Case 2 the range of complete hemolysis of sheep cells is not higher than that which may be infrequently found in normal human sera, accord-

" Attempts at the Experimental Production of Infectious Mononucleosis Antibodies in Rabbits." (Unpublished data.)
TABLE I

Agglutinins and hemolysins for sheep and ox red cells in the sera of cases of infectious mononucleosis *

\begin{tabular}{|c|c|c|c|c|c|c|c|c|}
\hline \multirow{3}{*}{ Serum collected } & \multicolumn{4}{|c|}{$\begin{array}{c}\text { Sheep red cells- } \\
\text { titers }\end{array}$} & \multicolumn{4}{|c|}{$\begin{array}{c}\text { Ox red cells- } \\
\text { titers }\end{array}$} \\
\hline & \multicolumn{2}{|c|}{$\begin{array}{c}\text { Agglu- } \\
\text { tining }\end{array}$} & \multicolumn{2}{|c|}{$\begin{array}{l}\text { Hemo- } \\
\text { lysins }\end{array}$} & \multicolumn{2}{|c|}{ Agglutinins } & \multicolumn{2}{|c|}{$\begin{array}{l}\text { Hemo- } \\
\text { lysins }\end{array}$} \\
\hline & $4+$ & + & $4+$ & + & $4+$ & + & $4+$ & + \\
\hline $\begin{array}{l}\text { Case 1-F. C. } \\
\text { December 12, } 1933 . . \\
\text { December 19, } 1933 . . \\
\text { March 20, } 1934 \nmid \ldots .\end{array}$ & $\begin{array}{r}500 \\
480 \\
0\end{array}$ & $\begin{array}{r}1,170 \\
1,920 \\
0\end{array}$ & $\left|\begin{array}{r}500 \\
500 \\
40\end{array}\right|$ & $\left|\begin{array}{r}1,225 \\
1,625 \\
84\end{array}\right|$ & $\begin{array}{l}\mathbf{0} \\
\mathbf{0} \\
\mathbf{0}\end{array}$ & $\begin{array}{r}\mathbf{0} \\
\mathbf{0} \\
\mathbf{2 0}\end{array}$ & $\left|\begin{array}{r}1,280 \\
1,000 \\
15\end{array}\right|$ & $\begin{array}{r}7,680 \\
2,830 \\
40\end{array}$ \\
\hline $\begin{array}{l}\text { Case } 2-N . \text { H. } \\
\text { July } 13,1934 \ldots \ldots \ldots \\
\text { July 16, } 1934 \ldots \ldots \ldots \\
\text { July 18, } 1934 \ldots \ldots \\
\text { September } 17,1934 \dagger\end{array}$ & & $\begin{array}{r}1.024 \\
500 \\
350 \\
8\end{array}$ & $\begin{array}{r}128 \\
100 \\
70 \\
8\end{array}$ & $\begin{array}{r}400 \\
500 \\
230 \\
24\end{array}$ & $\begin{array}{l}\mathbf{0} \\
\mathbf{0} \\
\mathbf{0} \\
\mathbf{0}\end{array}$ & $\begin{array}{l}\mathbf{0} \\
\mathbf{0} \\
\mathbf{0} \\
\mathbf{8}\end{array}$ & $\begin{array}{r}128 \\
114 \\
8\end{array}$ & $\begin{array}{r}1,230 \\
1,000 \\
32\end{array}$ \\
\hline $\begin{array}{l}\text { Case 3-F. W. } \\
\text { September 22, 1934.. }\end{array}$ & 512 & 4,096 & $\left.384\right|_{2}$ & 2,048 & $32 \ddagger$ & $1,024 \ddagger$ & 1,536 & 6,400 \\
\hline
\end{tabular}

* The agglutinin titers reported by previous authors (Paul and Bunnell, Boveri, Bunnell, Bernstein) were given in terms of the highest dilutions of serum showing definite $(+$ or \pm ) macroscopic agglutination. In this table complete and definite reactions are both recorded in order to better demonstrate the parallelism of agglutinins and hemolysins for sheep red cells.

† Sera obtained some time after complete clinical recovery.

$¥$ Cells easily stirred up in all tubes-definite but loose agglutination.

ing to the values given by Bailey and Shorb (1933b) and by Davidsohn (1929) who found titers between 128 and $256^{5}$ in 2.1 per cent of 379 persons tested. Normal agglutinins are much lower, however, for in a series of 450 normal adult human beings reported by Davidsohn (1930), 19 cases (4.2 per cent) showed agglutinins and the average titer of these antibodies was 8.

As shown in the table, the hemolysins for ox erythrocytes were found to be quite high and present in greater concentration than the sheep cells hemolysins, though appreciable agglutination of these cells was found only with the serum of Case 3. Unlike the sheep cells agglutinated by sera from these cases, the ox cells were very easily shaken loose even in the tubes containing the greatest concentrations of serum. A comparison with the titers found in a small series of nor-

\footnotetext{
5 Values " corrected" to conform to our expression of titer as the units of antibody per cubic centimeter of serum.
} 
mal sera is afforded by Table II. Eighteen of twenty sera tested showed agglutinins, 10 being the average titer. Complete hemolysis in dilution of 1 to 4 or above was shown only by two sera, while definite hemolysis, found in nineteen cases, showed an average + titer of only 8 . Davidsohn (1930) has reported a lower incidence of ox cell agglutinins in normal sera than shown here. According to this investigator they occurred in 25 per cent of 55 persons. The average titer of 8 which he found was of the same degree of magnitude as reported in Table II.

TABLE II

Agglutinins and hemolysins for ox red cells in normal human sera

\begin{tabular}{|c|c|c|c|}
\hline \multirow{3}{*}{ Serum number } & \multicolumn{3}{|c|}{ Ox red cellg-titers } \\
\hline & \multirow{2}{*}{$\frac{\text { Agglutinins }}{+}$} & \multicolumn{2}{|c|}{ Hemolysins } \\
\hline & & $4+$ & + \\
\hline 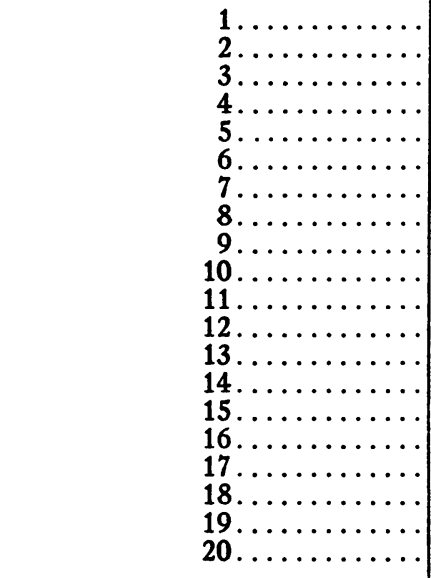 & $\begin{array}{r}8 \\
0 \\
0 \\
8 \\
32 \\
8 \\
16 \\
16 \\
16 \\
4 \\
8 \\
8 \\
4 \\
8 \\
8 \\
8 \\
8 \\
16 \\
4 \\
4\end{array}$ & $\begin{array}{r}0 \\
0 \\
10 \\
0 \\
0 \\
0 \\
0 \\
0 \\
0 \\
0 \\
0 \\
0 \\
0 \\
4 \\
0 \\
0 \\
0 \\
0 \\
0 \\
0\end{array}$ & $\begin{array}{r}10 \\
10 \\
20 \\
2 \\
24 \\
6 \\
2 \\
8 \\
8 \\
6 \\
2 \\
2 \\
6 \\
12 \\
4 \\
4 \\
4 \\
8 \\
4 \\
0\end{array}$ \\
\hline Average titer of positives. . . . . & 10 & \pm & 8 \\
\hline
\end{tabular}

It is evident then, that ox cell antibodies in the form of lysins are present in high concentration in infectious mononucleosis, and that these disappear with recovery. The agglutinins are apparently increased only in certain cases, and to a limited extent. Thus, in one instance these were below the normal average value, as illustrated by the relative titers during and after illness in Case 2. An increase of ox cell antibody titer in human beings has been reported in but one circumstance of which we are aware; following serum therapy. Davidsohn (1930) reported an increase of agglutinins for ox cells, among others, following injec- tions of horse serum, but this did not occur so regularly nor to such an extent as the increase of agglutinins for sheep cells. In most patients who did not have them before injection, they appeared after the onset of serum sickness. Deicher (1926) had previously found, in a series of patients treated with horse and sheep serum, definite agglutinins for sheep and ox cells as well as a variety of other erythrocytes. Davidsohn (1929) considers that the increase of antibodies for cells other than those of the sheep may be due to a nonspecific stimulation, since such immune bodies are already normally present in human serum. This author does not mention what titers were obtained with the ox cells, but his discussion leaves the impression that they were quite low.

The presence of ox as well as sheep cell antibodies in this disease did not of itself, of course, indicate necessarily that the antibodies for sheep cells were not heterophile in nature. The possibilities were naturally considered that either the antibodies for the two types of cells coexist as responses to an etiological factor containing antigenic components in common with both types of erythrocytes, or that one or the other, or both were the result of non-specific stimulation. This latter view seems hardly probable for reasons which will be discussed further on. A number of experiments given below demonstrate the true nature of the antibodies found in this disease.

Absorption tests. The samples of serum of which the titers are recorded in Table I were used in all tests done. Table III illustrates the results of absorption tests carried out with sera obtained during the courses of illness in the three cases. Only the more important or doubtful tests were repeated with the sera of Cases 2 and 3. For convenience of discussion the tests are separated into groups.

In the first group of tests carried out, sheep and ox erythrocytes were used for absorption. It is immediately evident that the antibody can be absorbed by either of these cells for themselves and each other. Since the antibodies against sheep cells are absorbed by ox cells, and ox cells do not contain heterophile antigen, it is apparent that these are not heterophile antibodies. ${ }^{6}$ The anti-

- After completion of this paper, a communication by Stuart, Burgess, Lawson and Wellman (Arch. Int. Med., 
bodies are a response to an antigenic component which these cells have in common. In the introduction a discussion has been given of the socalled isophile antigen, a thermolabile substance common to both sheep and ox erythrocytes. Here, however, it is seen that boiled and autoclaved corpuscles of both species are as effective as the fresh cells in absorbing antibody. The conclusions which may be drawn from this are either (1) the antigenic component concerned in this case is not isophile but some unknown antigen common to ox and sheep cells which is heat stable, or (2) that heating destroys the antigenic power of isophile antigen so far as its ability to stimulate antibodies is concerned, but leaves a heat stable hapten which possesses the power to absorb such antibodies. We are not aware that work has been done to demonstrate the presence of such a hapten in the isophile antigen. In a later report we shall discuss the results of attempts to establish the antigenic relationship of the heated corpuscles of the two species to the isophile component of these cells. It may be stated here that the isophile antigen has been found to contain no thermostable hapten, and that it apparently bears no relationship to the heat stable component responsible for absorption of mononucleosis antibodies.

It is interesting to note that the antigen in the ox erythrocytes is broader than that in the sheep cells, for the former removes antibodies against sheep cells to a greater degree than the sheep cells absorb ox hemolysins. In Cases 2 and 3 in particular the sheep cells do not completely remove antibodies even against themselves; as a matter of fact, these agglutinins are removed better by the heterologous ox corpuscles. An explanation for this is difficult to conceive, unless it is that the sheep antigen-antibody combination is a loose one, allowing some dissociation during the manipulations involved in the absorption test.

It may be stated that on the basis of the results of previous investigations as well as our own

1934, 54, 199-214) appeared, dealing with the cytological and serological aspects of infectious mononucleosis. The authors found that the antibodies were not absorbed by guinea pig kidney or testicle, and conclude that "certain facts must be explained before the heterophile nature of the antibody in mononucleosis can be unreservedly accepted." work, antibodies of the type seen here are not found in normal human serum. That the antibodies for sheep cells in such serum are heterophile is well known and has been recently demonstrated with bacteria by Bailey and Shorb (1933b) and Shorb and Bailey (1934), who found that all natural human anti-sheep hemolysins were absorbed by $B$. lepisepticus 370 , pneumococcus, Strep. viridans, $M$. catarrhalis, and partially by $B$. anthracis, $B$. faecalis alcaligenes, $B$. paratyphosus $B$ and $B$. aertrycke. These bacteria contain heterophile antigen. We have found, however, that such normal antibodies are not absorbed by ox erythrocytes. It has been discussed before that immune bodies for ox cells are found in normal human blood. Davidsohn (1930) has shown that they are not related to the presence of sheep cell antibodies, for in a group of 55 normal individuals, of those sera having no agglutinins for ox blood, almost one-half had agglutinins for sheep blood. The ox cell antibodies are increased in serum sickness, as shown by Deicher (1926) and Davidsohn (1930). The former author found that these are absorbed only by the homologous cells.

In two of the three cases with which this report deals, samples of serum were obtained some time after complete recovery from the illness. The essentially normal titers of these sera for ox and sheep corpuscles are shown in Table I. Absorption tests were carried out with both these sera. In Case 1 the sample was taken three and one-half months after recovery. Tests showed that whereas the antibodies for sheep cells were completely removed by carp gill suspension (heterophile tissue), fresh and autoclaved ox cells did not absorb them to the slightest degree. This seems to us to be of especial significance for this person had comparatively recently been subjected to the stimulatory factor responsible for such antibodies. The serum of Case 2 was obtained not quite two months after recovery, and though the antibodies were found to be low for sheep and ox cells, they were not all of the heterophile type for the former cells. Absorption with carp gill removed about 60 per cent of sheep hemolysins, whereas ox red cells took out about 40 per cent of these hemolysins. Apparently this determination was made at a time when the infectious mononucleosis antibodies had almost completely dis- 
TABLE III

Absorption tests with various heterophile and non-heterophile antigens and the sera of cases of infectious mononucleosis

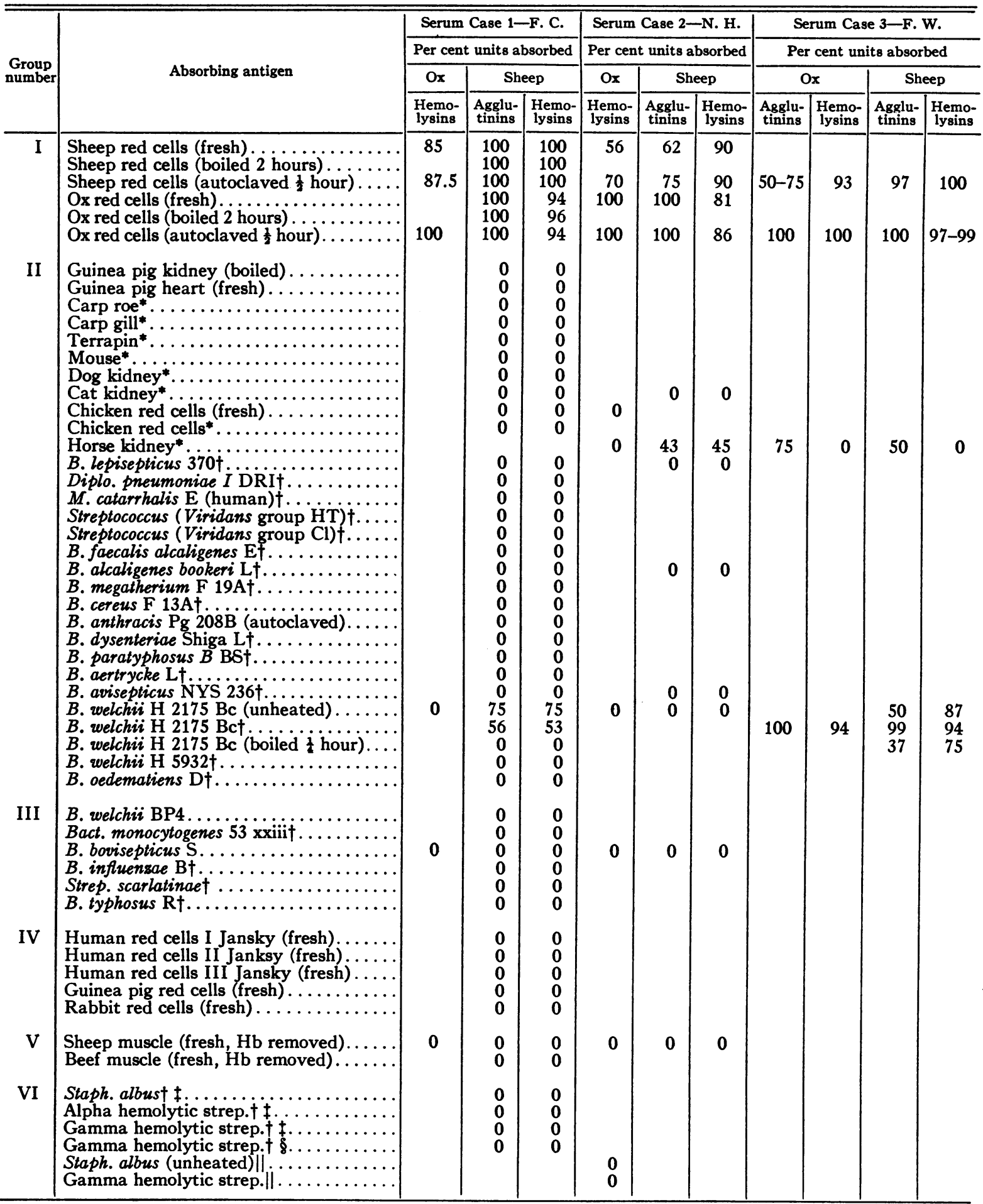

* These tissues were boiled for $\frac{1}{2}$ hour on two successive days. Their heterophile antigen properties and content were intact.

$\dagger$ Bacterial suspensions heated at $70^{\circ} \mathrm{C}$. for $\frac{1}{2}$ hour.

$\ddagger$ Nose and throat cultures from Case 1 .

Bacterium isolated from mouse injected with nose and throat swab washings of Case 1.

II Throat cultures from Case 2. 
appeared, so that the normal heterophile immune bodies had again become manifest.

These indications that antibodies of the type found in this disease are not a constituent of normal human serum suggest that they are a response to a specific etiological factor, either extrinsic or intrinsic, rather than the result of a non-specific stimulation as the consequence of an infectious or other process.

In the second group of tests absorption was carried out with all the tissues and practically all the bacteria known to contain the Forssman antigen. Of the tissues, most of which are known to be very polyvalent in their power to absorb heterologous heterophile antibodies, none removed the immune bodies for sheep corpuscles except horse kidney, which was quite irregular in even the moderate activity which it displayed. That horse kidney contains any component other than the heterophile antigen in common with sheep cells is very doubtful, in view of the fact that Bailey and Shorb (1933a) and Shorb and Bailey (1934) showed that the sheep cell hemolysin in anti-horse kidney rabbit serum is completely absorbed by various heterophile bacteria, and that similar tests which we have done failed to indicate such a relationship. It is seen that whereas the other antigens which successfully absorbed removed both agglutinins and lysins for sheep cells, horse kidney showed irregularity in this respect. The results obtained may be due, we believe, to excessive physical absorption by this tissue.

With the heterophile bacteria used in Group II of the tests, absorption of immune bodies was found only with one strain of $B$. welchii ( $\mathrm{H} 2175$ $\mathrm{Bc}$ ). The organisms which were completely negative have been extensively investigated as to their heterophile properties by Bailey and Shorb (1931, 1933a and b) and Shorb and Bailey (1934), who originally found the antigen in many of these bacteria. These authors state that ". . . some species, including $M$. catarrhalis (human), B. avisepticus, Strep. viridans, along with the Diplo. pneumoniae and B. lepisepticus heterophile cultures, have antigens with marked affinity for heterologous as well as homologous hemolysin. It is readily apparent that $B$. lepisepticus $370, B$. avisepticus NYS 236, Diplo. pneumoniae DRI, Strep. viridans $\mathrm{Cl}$, and to a less extent $M$. catar- rhalis $\mathrm{E}$ have a great affinity for the hemolysins produced in rabbits by most heterophile antigens whether bacterial or tissue. These results seem especially significant when it is considered that these organisms, in comparison with the other bacteria containing heterophile antigen, produce high hemolytic titers in rabbits when only very small amounts of the cultures are injected. These organisms apparently contain relatively large amounts of the antigen (taking into consideration the possible effect of chemical differences in antigens on heterologous absorption)." An example of this is afforded by the finding of these authors that each 0.1 to $0.2 \mathrm{cc}$. of sedimented bacteria (Diplo. pneumoniae DRI and B. lepisepticus 370 ) from $50 \mathrm{cc}$. of broth culture absorbed almost 2,000 units of hemolysin from Type I antipneumococcus rabbit serum. Each 10 units (0.1 to $0.2 \mathrm{cc}$.) of boiled sheep red cells removed 760 units of hemolysin from the same serum. It has been stated before that these investigators found normal human heterophile antibodies to be absorbed by these bacteria as well as the rabbit serum hemolysins.

The removal of antibodies by $B$. welchii $\mathrm{H} 2175$ $\mathrm{Bc}$ is seen to be irregular in several respects. In the first place antibodies were not absorbed from the serum of Case 2 at all. With the serum of Case 1 the removal of antibodies for sheep cells was effected by unheated bacteria or organisms heated at $70^{\circ} \mathrm{C}$. for 30 minutes, but not with bacteria which had been boiled for 15 minutes. In view of the heat stability of the antigen in ox and sheep erythrocytes this is not explicable, yet the tests were repeated several times with the same results. Furthermore, even the unheated bacteria did not absorb the ox cell lysins. However, in Case 3, the heated and unheated bacteria absorbed both sheep and ox antibodies. The results with this bacterium were so regular in the cases where absorptive activity was displayed (i.e., both agglutinins and hemolysins were removed) that it is difficult to consider the reactions other than as examples of specific absorption. Another strain of the same bacterium ( $H$ 5932) which also has been shown by Shorb and Bailey to contain the Forssman antigen, did not absorb the antibodies.

No simple explanation is available to us for the irregularities of absorption by $B$. welchii $\mathrm{H} 2175$ 
Bc which were observed. But if despite this we assume that this antigen under certain conditions is capable of specific absorption of the infectious mononucleosis antibodies, the comments of Shorb and Bailey on the nature and properties of the heterophile antigen contained in this particular strain of $B$. welchii are of much interest. These authors state: "It can be concluded ... . that the heterophile antigens contained in some species of bacteria, especially that of ...B. oedematiens, $B$. welchii as well as $B$. paratyphosus $B$ and $B$. dysenteriae Shiga are quite specific since even the homologous strain or other strains of the same species may not absorb completely the species hemolysin. $B$. welchii antiserum $(\mathrm{H} 2175 \mathrm{Bc})$ is of interest because with certain samples very little absorption was noted with any of the bacteria except the homologous antigen. In some cases the hemolysin was not even absorbed by any of the heterophile tissue antigens which are known to have a great affinity for heterologous heterophile hemolysin. The significance of the lack of combining ability is not known. It may be that this particular organism, besides producing heterophile hemolysin, produces an hemolysin of another type not entirely related to the receptors found in sheep cells or guinea pig tissues."

Agglutination tests were done with the serum of Case 1 and the three strains of $B$. welchii used in the absorption tests ( $\mathrm{H} 2175 \mathrm{Bc}$ and $\mathrm{H} 5932$ are supposed heterophile strains, while BP4 is non-heterophile). The tests were not conclusive. There was settling out of the $\mathrm{H} 2175 \mathrm{Bc}$ strain in tubes containing serum in dilution up to 1 to 10,240 , but no settling in control tubes containing normal human serum and saline. With the other two strains there was no settling in any tubes. This may be of some significance, for the fact that no clumping was seen may be due to the difficulty encountered in agglutination of encapsulated bacteria.

Group III of the tests includes a variety of non-heterophile bacteria which were tested more or less at random, though with regard to the symptoms of the diseases with which they are associated, with the object in mind that a possible etiological relationship to the disease might be encountered. Paul and Bunnell and Bernstein have already ascertained that patients with the diseases caused by most of these organisms (influ- enza, scarlet fever, typhoid fever) do not have increased titers for sheep cells. $B$. bovisepticus was tested because we found, in another connection, that it seems to have a peculiar agglutinogenic relationship to sheep erythrocytes. We were particularly interested in the test with Bact. monocytogenes. Murray, Webb and Swann (1926) discovered this organism as the etiological basis for a disease of rabbits characterized by a pronounced monocytosis. Dr. Murray kindly sent us this organism. The absorption tests which we carried out with it were negative. We were also interested in the apparently related organism, Bact. monocytogenes hominis of Nyfeldt (1929). Unfortunately, absorption tests with this bacterium were not reported by the author since the hemolytic antibodies associated with the disease were unknown at the time his work was done. If such an organism could be shown to absorb the specific type of ox and sheep cell antibodies discussed in this paper, a rather firm basis for its etiologic relationship to infectious mononucleosis would be established. We are attempting to carry out this phase of the problem at the present time.

The fourth group of tests was carried out with various erythrocytes, none of which absorbed. Of particular interest here is the human Group A (Jansky Group II) corpuscles. It is generally accepted that the Forssman antigen and human Group A agglutinogen are similar but not identical. Bernstein discusses the possibility that in infectious mononucleosis red cells are broken down with liberation of the antigen which subsequently produces the antibodies. He states further that there is ample evidence that such is not the case, since infectious mononucleosis and the sheep cell antibodies appeared in patients of other blood groupings with as great regularity as in Groups A or AB, nor did several patients receiving multiple transfusions with Group A blood develop an increased antibody titer. The tests reported here further minimize the possibility of normal red cells acting as an intrinsic stimulation for the antibodies found in this disease.

The remainder of the tests demonstrate that the antigen is not present in fresh beef or sheep muscle washed free of hemoglobin, and that nose and throat cultures from two of the patients failed to absorb hemolysins or hemagglutinins from the sera of these persons. 
Other tests for Forssman antibady. There are several methods for the demonstration of heterophile antibody besides those already discussed. Thus, both human and rabbit heterophile sera when introduced intravenously into guinea pigs are known to produce generally a syndrome very similar to anaphylactic shock, while intracutaneous injection into these animals causes a severe local necrotic reaction. This property of the serum is known as its primary toxicity. The work of a number of investigators has shown, however, that such primary toxicity does not parallel the heterophile antibody content of the sera in all instances, especially in the case of certain of the antibacterial heterophile sera. With these facts in mind we have tested the serum from a case of infectious mononucleosis by injection into the guinea pig. An intracutaneous test done with $0.2 \mathrm{cc}$. of serum from Case 2 with an agglutinin titer of 350 for sheep cells was entirely negative. We have not had an opportunity to carry out further tests with sera of higher titers for sheep cells.

Among the characteristic reactions manifested by heterophile hemolytic antibodies are (1) combination with emulsions of lipoids derived from heterophile tissues, and (2) formation of precipitates with emulsions of such lipoids. The heterophile lipoid is known to be soluble in alcohol. Such lipoid preparations, which have been found effective when used with known heterophile antibodies, were tested with the infectious mononucleosis sera for the above properties and found negative. Further studies with other solvents are now being made.

The value of ox cell absorption in the diagnosis of infectious mononucleosis. Abnormal titers of antibodies for sheep erythrocytes have been found consistently in human beings only in two conditions; following horse serum therapy and in infectious mononucleosis. Aside from these cases high concentrations of these immune bodies have been reported in isolated instances only. Ramsdell and Davidsohn (1930) reported a titer above the normal in a patient receiving injections of insulin. Paul and Bunnell discuss a fatal case in which the serological findings were those of infectious mononucleosis, but the clinical manifestations were too indefinite to permit a satisfactory diagnosis, so that it was classified as either aleukemic leukemia or aplastic anemia.
Despite the fact that the combination of diagnostic factors in infectious mononucleosis is such that the correct diagnosis would seem a comparatively simple matter, this is apparently not always the case. Bernstein, for example, reports a case in which the syndrome was that of thrombocytopenic purpura, accompanied by a high sheep cell agglutinin titer, and considers the possibility of a concurrent atypical infectious mononucleosis. Rosenthal and Wenkebach (1933) discuss the relationship of this disease to the group of conditions which they consider similar but distinct entities. This group includes lymphocytic angina, monocytic angina and glandular fever. These authors state that despite the lack of certain symptoms the diagnosis may be easily confirmed by the positive heterophile antibody reaction. In some of these cases agglutinin titers of 16 (which are sometimes found in normal individuals and after horse serum treatment) serve as the basis for including the disease under the classification of infectious mononucleosis.

In instances where reliance is placed chiefly on the sheep cell hemagglutinin titer for the diagnosis of this condition, two main sources of error are to be considered. In the first place Bernstein has pointed out that there is a wide range of antibody concentration in normal people, and "that if the increased titer of agglutinins in infectious mononucleosis merely represents an enhancement of the concentration of antibodies already present, then there is just as much increase in a patient's serum with a normal agglutinin titer of 1 to 1 , rising to 1 to 16 as there would be in one starting at 1 to 8 and rising to 1 to 128 . Yet the former would be considered a negative heterophile antibody test and the latter a positive one." Secondly, the possibility of a high heterophile titer due to previous horse serum injections is a factor of some importance. Davidsohn (1929) has pointed out that sheep cell agglutinins may persist for long periods after such treatment. In one patient these were present one year after injection of serum. In another who had received diphtheria antitoxin three years before, and in two similarly treated two years before, these immune bodies were still present. Bernstein emphasizes the importance of eliminating horse serum as an inciting agent before drawing any conclusions from an increased titer of heterophile antibodies. 
In the normal individuals whom we have tested, we have been able to find no antibodies of the nature of those found in infectious mononucleosis. Likewise, the cases of this disease which we have studied have shown the disappearance of these and the presence of the true heterophile antibodies after recovery, as discussed in a preceding section. From the fact also that previous investigators (Paul and Bunnell, Boveri, Bernstein) have shown that none of a large variety of pathologic conditions tested were characterized by the presence in the blood of sheep cell antibodies, and since such antibodies in serum sickness are actually heterophile in nature, we believe that the antibody seen in infectious mononucleosis is specifically characteristic of this disease. If it can be demonstrated that one immune body for both sheep and ox cells is present in measurable concentration in an individual suspected of harboring the infection, then so far as is known there is no serological basis to hinder classification of the condition as infectious mononucleosis. The logical manner in which such a test should be carried out is the primary titration of the serum with sheep cells and then absorption of the serum with boiled or autoclaved ox cells, followed by titration against sheep corpuscles. This method is advised because it provides immediate proof that one antibody is responsible for the activity of the serum against both species of erythrocytes. Furthermore, in addition to the commonly used sheep cells this method involves the use only of boiled ox cells, which can be kept sterile in the icebox almost indefinitely for use at any time.

The value of this type of test in certain vague conditions was especially impressed on us by a case in which we were interested as a possible example of infectious mononucleosis. A detailed report follows :

Case 4.7 H. M., an 8 year old white male, was admitted to the Jewish Hospital of Brooklyn on March 11, 1934, complaining chiefly of a fever of 10 days duration. The history indicated that the patient had suffered with diphtheria some time in the past.

On admission the child did not seem acutely ill. The skin was faintly tinged a lemon yellow and the pharynx

7 The authors are indebted to Dr. M. R. Greene of the Jewish Hospital of Brooklyn, New York, for supplying clinical data and serum in this case. was moderately injected. There was no adenopathy and the splenic margin was questionably palpable. During the past 10 days the temperature had been remittent up to $102^{\circ} \mathrm{F}$., though on two occasions it had risen to $105^{\circ}$ and $106^{\circ}$. There were no other complaints.

Through the first six days of hospitalization the temperature showed a daily intermittent course up to $103^{\circ}$ in the evening, being normal in the morning. There were still no other complaints. Nose and throat cultures as well as blood and spinal fluid cultures were negative during this interval. The Widal was negative on the day of admission and agglutination tests a week later with the $B$. melitensis and abortus group indicated no abnormality.

At the time of admission the total leukocyte count was 10,000 and the differential picture showed a monocytosis. Subsequent blood studies are illustrated in Figure 4. Of

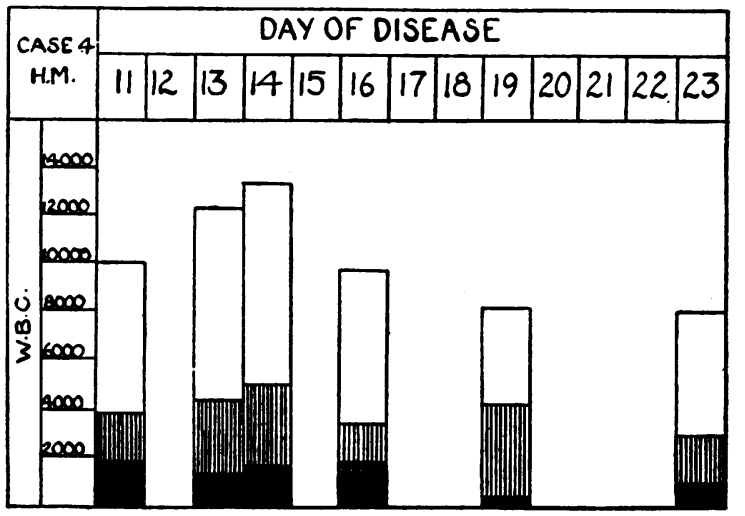

Fig. 4. A Suspected Case of Infectious MononuCLEOSIS IN Which ANtibodies fOR Ox ERYthrocytes WERE LACKING.

Legends as in Figure 1.

particular interest is the fact that two days later it was observed that 1 or 2 young lymphocytes were present, but the change in these cells was not striking. Three days after this, on March 16, the notation was made that 4 lymphocytes typical of the cells seen in infectious mononucleosis were found, though at this time the total lymphocyte percentage was only 21 . The degenerative index of polymorphonuclear cells was 64 per cent, indicating a toxic blood picture. The impression recorded in the history on this date was that of infectious mononucleosis. The next day agglutinins for sheep cells were found in 1 to 32 dilution of this patient's serum.

Several days later no abnormal lymphocytes were found, so that the possibility of infectious mononucleosis was excluded.

The patient continued to run a septic temperature daily with no chills and no other complaints. On April 7, 1934, he was discharged from the hospital with the fever undiagnosed. 
A sample of serum from this patient was obtained on March 31, thirty days after the beginning of the illness. At this time the titer for sheep cells was quite high, complete lysis being found in dilution of 1 to 160 . The agglutinins were not parallel, being definitely positive through 1 to 16 dilution. Hemolysins for ox cells were of a low normal value. Absorption tests with this serum showed that ox cells did not remove the sheep cell antibodies, whereas carp gill and guinea pig kidney did. The antibodies were therefore heterophile and as such not compatible with the findings made in infectious mononucleosis. It was mentioned in the case report that this child had a history of diphtheria. We were unable to ascertain how long before the present illness he had suffered with this disease nor whether antitoxin had been administered. There is obviously a possibility that the sheep cell antibodies found might have had their origin from the treatment of the earlier illness.

\section{DISCUSSION AND SUMMARY}

Previous investigators who have reported on the antibody responses in infectious mononucleosis have used the terms heterophile or Forssman antibody in describing the sheep red cells agglutinin and hemolysin first observed by Paul and Bunnell in this disease. It has been assumed that these immune bodies are true Forssman antibodies because of their action on sheep cells, although no tests with other heterophile or non-heterophile antigens are recorded.

The complex relationships between the antigenic components of various species of red blood cells and tissues and the corresponding antibodies have led to a confusing terminology in their description, but the essential points concerning these relationships are quite simple and are well known. The antigenic substances that incite the production of hemolysins in the rabbit for sheep erythrocytes have been divided into two classes, heterophile and isophile. The heterophile antigens most commonly mentioned include the red cells of the sheep and goat, the organs of the guinea pig, horse, cat, dog, mouse, chicken, tortoise, certain kinds of fish and several varieties of bacteria. The common non-heterophile antigens include the organs of the rabbit, ox, pig, man, rat, goose, pigeon, frog, etc. Animals whose organs or red cells contain heterophile antigen are sometimes classed as of the "guinea pig type"; those which do not, the " rabbit type." The red cell of the ox is generally mentioned as an example of a typical isophile antigen, while the phylogenetically closely related sheep red cell contains both heterophile and isophile components. Both of these types of antigens can be recognized and defined in terms of the behavior of their antibodies. It has generally been stated that a true heterophile hemolytic antibody is completely removed from its serum by boiled sheep red corpuscles (and heterophile tissues, such as guinea pig kidney, etc.), while the isophile hemolysin is absorbable only by unheated sheep or ox corpuscles. The hemolysins produced in the rabbit by the injection of native sheep corpuscles possess both heterophile and isophile properties. Sheep corpuscles therefore contain at least two kinds of lysinogens,-a heterophile fraction which is thermostable and an isophile component which is thermolabile. This fact is demonstrated not only by the reactions of anti-sheep hemolysins toward native and boiled sheep cells, but also by the fact that only heterophile immune body results when the boiled cells are injected into rabbits.

The red cells of the ox incite in the rabbit hemolytic antibodies for the red cells of the sheep as well as for the homologous cells. The ox cell is of isophile type, since its antibody combines only with the thermolabile receptors of sheep and ox corpuscles. Hyde (1925) has shown that this anti-ox hemolysin is removed from its serum by native, but not by boiled corpuscles of these two species.

The results of previous investigations have shown then that sheep and ox erythrocytes are related antigenically through their thermolabile components, while the thermostable components of these two species of cells have not been shown to have anything in common. The results of our own study with these erythrocytes demonstrate a relationship between certain thermostable fractions of these cells as indicated by the ability of autoclaved ox and sheep erythrocytes mutually to cross absorb the hemolytic and hemagglutinative antibodies for both of these species of cells from the serum of patients with infectious mononucleosis. Our results demonstrate further that the 
antibodies in infectious mononucleosis are not of the heterophile (Forssman) type. They are probably the response to an antigen which is similar to a hitherto unknown heat stable component of the ox and sheep erythrocyte, and also of a bacterium, $B$. welchii $\mathrm{H} 2175 \mathrm{Bc}$, and possibly of horse kidney. Immune bodies of this type apparently are not a constituent of normal human blood, nor are they found in any of a large variety of pathological conditions as indicated by an analysis of the data of previous investigators who have been concerned with the heterophile antibody content of such sera. They are therefore limited strictly to this disease and for this reason may serve as the basis for a diagnostic test, particularly when other features of the syndrome cannot be distinguished with certainty, and even though the history indicates previous horse serum therapy. Cases have been reported (Bernstein) wherein the clinical findings were those of infectious mononucleosis but appreciable agglutinins for sheep erythrocytes were lacking. Whether such instances would show high titers for ox cells we have had no opportunity to determine, but obviously observations on this point would be of much interest. We believe that even when high titers for ox erythrocytes cannot be found, the demonstration that such low concentration of antibody as is present is of the type reported in this paper would serve to class the disease as infectious mononucleosis.

The etiology of this condition is still a matter of conjecture. The peculiar properties of the antibody concerned gives us, however, a more definite basis than was heretofore available for testing the possible relationship of various bacteria or other factors to the disease. Since the antibody is characteristic of this condition and is not found in normal serum, we believe that it is a specific response to a definite factor, either intrinsic or extrinsic, rather than a reaction due to nonspecific stimulation. The recognition of an extrinsic factor which would combine with this immune body should logically supply a strong indication that it plays a specific part. On the other hand, we may conclude from the fact that nose and throat organisms from our own cases failed to absorb these antibodies, that if the responsible causative agent is found in these regions, it is not culturable on ordinary media.
In this connection it is interesting that abnormal concentrations of bacterial agglutinins are present in some cases of this disease. Bernstein has reported instances in which agglutinins for the typhoid and suipestifer groups of organisms were found. Case 1 reported here was one of the patients showing such antibodies for the typhoid group, while Case 2 agglutinated $B$. melitensis to an abnormal degree. Some of these bacteria have been tested for their ability to absorb the mononucleosis antibodies, and have been found negative. In view of this, and also because the antibacterial response is seen in only few cases, and not to the same bacteria in these instances, we are inclined to favor the opinion held by Bernstein that such agglutinins are not specifically related to the disease. They are probably the result of non-specific stimulation.

A consideration of the serological findings in this condition brings up several points of theoretical interest. The sheep cell agglutinin titers parallel those for hemolysins. With the exception of the isoagglutinins of the human blood groups and the autohemagglutinins in rabbits following repeated blood transfusions, we know of no instance either in human beings or experimental animals where the agglutinins for erythrocytes of any kind are as high as the hemolysins. In most cases the former do not even approach the latter. Our knowledge of the properties of human anti-erythrocyte sera is necessarily very limited, of course. It may possibly be that investigation of the responses of the immunized human being to various corpuscles would disclose a natural tendency of this species to produce higher agglutinin titers than are found in experimental animals.

The controversial ideas concerning the essential identity of antibodies, generally termed the unitarian hypothesis, are too well known to warrant discussion here. We merely wish to comment on the possible bearing of certain results reported in this communication on this theory. It was seen that ox erythrocytes remove both agglutinins and hemolysins for sheep corpuscles. It seems very improbable that the ox cell would contain two factors, one with an affinity for the agglutinin and the other with an affinity for the hemolysin. It seems to us rather more probable that one antigenic component is responsible for the absorption of both immune body manifestations. 


\section{CONCLUSIONS}

1. The hemolytic and hemagglutinative antibodies for sheep and ox red cells found in the sera of cases of infectious mononucleosis are not heterophile or Forssman antibodies, but are probably the specific response to an antigen having a factor in common with a thermostable component of sheep and ox erythrocytes, a certain strain of $B$. welchii ( $\mathrm{H} 2175 \mathrm{Bc}$ ), and possibly horse kidney.

2. These antibodies have the power to hemolyze and agglutinate not only sheep red cells, but also to hemolyze and to some extent agglutinate ox red corpuscles, although these immune bodies are not isophile in nature since they are absorbed from the serum by boiled ox and sheep corpuscles.

3 . Ox erythrocytes have a broader antigenic relationship to the antibodies of infectious mononucleosis than sheep erythrocytes.

4. The antibodies are probably not found in normal human serum, but are rather a specific response associated with infectious mononucleosis only.

5. These antibodies were not absorbed from the serum by any of the organisms cultivated from the upper respiratory tract of cases of the disease.

6. Blood cultures made from cases of infectious mononucleosis were negative, although the injection into rabbits of such cultures, containing the blood elements of a patient, caused the production of a serum with a high hemolytic titer for sheep cells.

7. The antibodies in infectious mononucleosis and the thermostable antigen in ox and sheep cells which combine with and neutralize them have unique properties of specificity which so far as we are aware have not been described before.

8. The primary titration of a serum with fresh sheep erythrocytes followed by absorption of the antibodies with boiled ox red cells and then retitration of the absorbed serum with fresh sheep corpuscles, provides a specific diagnostic method for this disease.

\section{BIBLIOGRAPHY}

Bailey, G. H., and Shorb, M. S., Heterophile antigen in pneumococci. Am. J. Hyg., 1931, 13, 831.

Bailey, G. H., and Shorb, M. S., Chemical and immunological properties of pneumococci and other heterophile antigens. Am. J. Hyg., 1933a, 17, 329.
Bailey, G. H., and Shorb, M. S., Immunological relationships of pneumococci and other heterophile antigens and biological significance in pneumococcus infections. Am. J. Hyg., 1933b, 17, 358.

Bernstein, A., Antibody responses in infectious mononucleosis. J. Clin. Invest., 1934, 13, 419.

Boveri, R., Utber das Vorkommen Heterophiler Antikörper bei Lymphoidzelliger Angina. Klin. Wchnschr., 1933, $12,666$.

Bunnell, W. W., A diagnostic test for infectious mononucleosis. Am. J. M. Sc., 1933, 186, 346.

Davidsohn, I., Heterophile antibodies in serum sickness. J. Immunol., 1929, 16, 259.

Davidsohn, I., Further studies on heterophilic antibodies in serum sickness. J. Immunol., 1930, 18, 31.

Davidsohn, I., and Ramsdell, S. G., Horse serum as a heterophilic antigen. I. J. Immunol., 1929, 17, 365.

Davidsohn, I., and Ramsdell, S. G., The toxicity of human serum for the guinea pig as affected by absorption of agglutinins. J. Immunol., 1930, 18, 23.

Deicher, H., Uber die Erzeugung heterospezifischer Hämagglutinine durch Injektion artfremden Serums. Ztschr. f. Hyg., 1926, 106, 561.

Forssman, J., Die Herstellung hochwertiger spezifischer Schafhämolysine ohne Verwendung von Schafblut. Ein Beitrag zur Lehre von heterologer Antikörperbildung. Biochem. Ztschr., 1911, 37, 78.

Friedemann, U., Uber heterophile Normalamboceptoren. Ein Beitrag zur Lehre von der Entstehung der normalen Antikörper. Biochem. Ztschr., 1917, 80, 333.

Gorham, L. W., Smith, D. T., and Hunt, H. D., The experimental reproduction of the blood picture of infectious mononucleosis in the guinea pig. J. Clin. Invest., 1929, 7, 504.

Hyde, R. R., The specificity of hemolytic antibodies. Am. J. Hyg., 1925, 5, 217.

Landsteiner, K., and van der Scheer, J., On the antigens of red blood corpuscles. II. Flocculation reactions with alcoholic extracts of erythrocytes. J. Exper. Med., 1925, 42, 123.

Murray, E. G. D., Webb, R. A., and Swann, M. B. R., A disease of rabbits characterised by a large mononuclear leucocytosis, caused by a hitherto undescribed bacillus Bacterium monocytogenes ( $n$. sp.). J. Path. and Bact., 1926, 29, 407.

Nyfeldt, A., Etiologie de la mononucléose infectieuse. Compt. rend. Soc. de biol., 1929, 101, 590.

Paul, J. R., and Bunnell, W. W., The presence of heterophile antibodies in infectious mononucleosis. Am. J. M. Sc., 1932, 183, 90.

Ramsdell, S. G., and Davidsohn, I., The toxicity of human serum for the guinea pig. J. Immunol., 1930, 18, 473.

Rosenthal, N., and Wenkebach, J., Die Bedeutung der Heterophilen Antikörperreaktion für die Diagnose der Infektiösen Mononucleose. Klin. Wchnschr., 1933, 12, 499.

Shorb, M. S., and Bailey, G. H., Heterophile antigen in various bacterial species. Am. J. Hyg., 1934, 19, 148. 